Images in...

\title{
Ocular trauma: a sticky situation
}

\author{
C J Chu, S A Rayner
}

Department of Ophthalmology, Cheltenham General Hospital, Cheltenham, UK

Correspondence to C J Chu, colin.chu@doctors.org.uk

\section{DESCRIPTION}

A 38-year-old man was struck by a branch in the right eye while riding a quad bike between trees. In the emergency department he was documented to have a seemingly intact globe, but with a linear corneal laceration and a small hyphaema presumably secondary to blunt trauma (figure 1). There was no evidence of aqueous leakage after the application of fluorescein and the anterior chamber was formed.

Ophthalmology review was obtained and, despite the apparently intact globe, penetration was confirmed during exploration under general anaesthetic. A small strand of iris had plugged the defect.

After primary corneal repair, a traumatic cataract and vitreous floaters became evident. During subsequent cataract extraction and vitrectomy, a posterior capsule tear and spontaneously healed retinal laceration corresponding to the corneal wound were noted. We postulate that the eye deflated upon initial impact and rapidly reformed. This case emphasises the need to maintain a high suspicion of penetration following all ocular trauma. ${ }^{1}$

Competing interests None.

Patient consent Obtained.

\section{REFERENCES}

1. Wagner PJ, Lang GK. Mechanical ocular trauma. Curr Opin Ophthalmol 1996; 7:57-64.

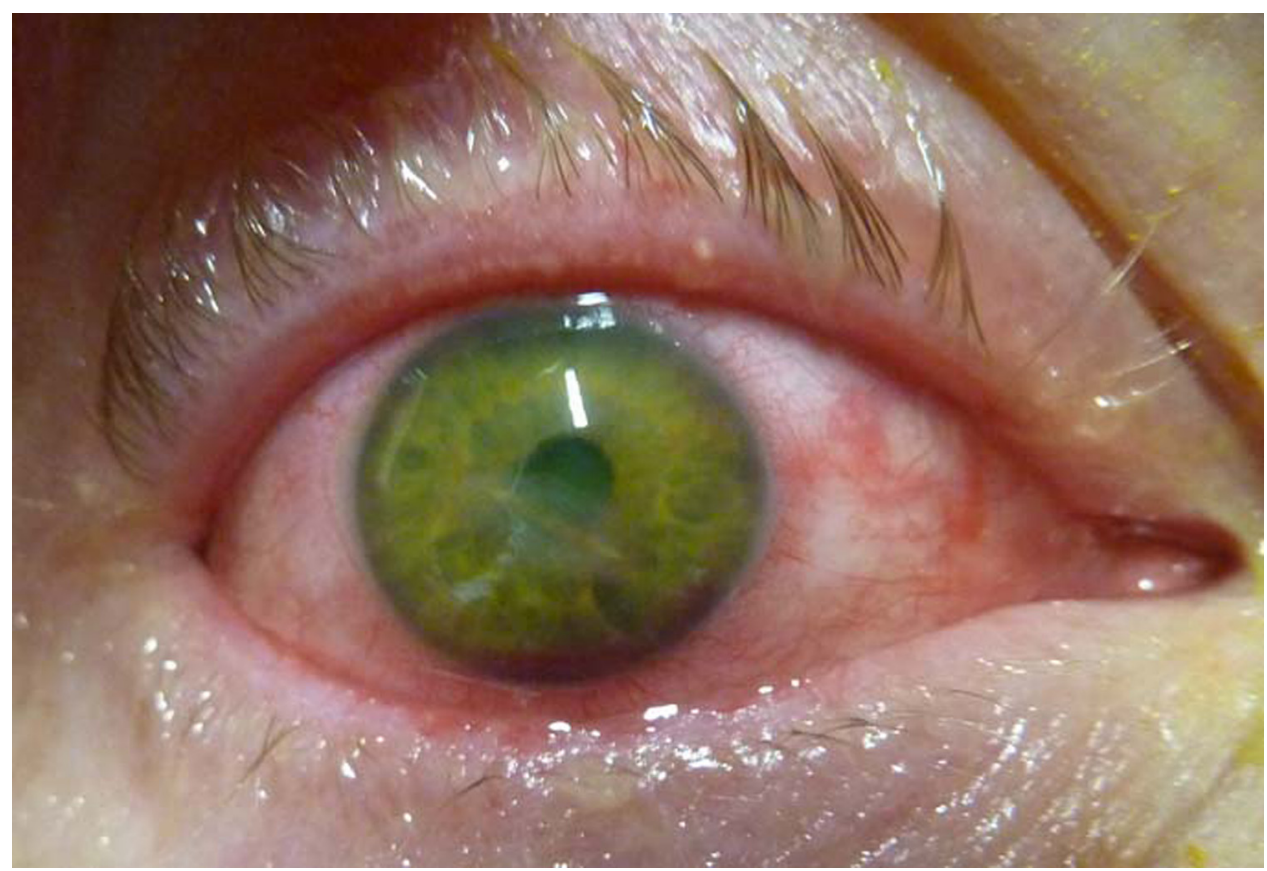

Figure 1 Complete globe penetration has occurred, but the eye appears formed. 


\section{BMJ Case Reports}

This pdf has been created automatically from the final edited text and images.

Copyright 2010 BMJ Publishing Group. All rights reserved. For permission to reuse any of this content visit http://group.bmj.com/group/rights-licensing/permissions.

BMJ Case Report Fellows may re-use this article for personal use and teaching without any further permission.

Please cite this article as follows (you will need to access the article online to obtain the date of publication).

Chu CJ, Rayner SA. Ocular trauma: a sticky situation. BMJ Case Reports 2010;10.1136/bcr.10.2010.3399, date of publication

Become a Fellow of BMJ Case Reports today and you can:

- Submit as many cases as you like

Enjoy fast sympathetic peer review and rapid publication of accepted articles

Access all the published articles

Re-use any of the published material for personal use and teaching without further permission

For information on Institutional Fellowships contact consortiasales@bmjgroup.com

Visit casereports.bmj.com for more articles like this and to become a Fellow 